dr inz. Marek Sobaś, prof. IPS

Instytut Pojazdów Szynowych ,,TABOR”

\title{
Saffety of riding of freight wagons equipped with 1XTa bogies with leaf springs
}

\section{Bezpieczeństwo jazdy wagonów towarowych wyposażonych w wózki 1XTa z resorami piórowymi}

\begin{abstract}
The paper presents the problem of safety against derailment of freight wagons, equipped with IXTa bogies with leaf springs. One of the important safety elements is the leaf spring, which is installed in the primary suspension. It discusses the ways of qualifying the springs for the further use, aimed at ensuring the safe riding against derailment.

$W$ artykule przedstawiono problem bezpieczeństwa przed wykolejeniem wagonów towarowych, wyposażonych $w$ wózki 1 XTa z resorami piórowymi. Jednym $z$ istotnych elementów bezpieczeństwa jest resor piórowy, który jest zainstalowany $w$ zawieszeniu pierwszego stopnia. Omówiono sposoby kwalifikacji resorów do dalszej eksploatacji, majace na celu zagwarantowanie bezpiecznej jazdy przed wykolejeniem.
\end{abstract}

\section{INTRODUCTION}

The safety against derailment of freight wagons, equipped with $1 \mathrm{XTa}$ bogies with their variants has a long history. It must be taken into account that the 1XTa bogies with the variants have a base of 2000 $\mathrm{mm}$ and they were considered in the standardization process $[1,6]$. The 1XTa bogie was submitted for standardization by PKP. The criterion, that rejected it, was the failure to meet the required bogie base, which, according to the ORE/ERRI B12/Rp14/D report [6], should be $1800 \mathrm{~mm}$. The bogie base had an impact on the criterion of interchangeability (Austauschbarkeit). In this way, the Y25C and DB 665 bogies were qualified for the next standardization work. A border was

\section{WSTĘP}

Bezpieczeństwo przed wykolejeniem wagonów towarowych, wyposażonych w wózki $1 \mathrm{XTa}$ wraz $\mathrm{z}$ ich odmianami ma swoja długa historię. Należy wziać pod uwagę, że wózki 1XTa wraz z odmianami mają bazę $2000 \mathrm{~mm}$ i były brane pod uwage $\mathrm{w}$ procesie standaryzacji $[1,6]$. Wózek 1 XTa został zgłoszony do standaryzacji przez PKP. Kryterium, które zadecydowało o ich odrzuceniu, był brak spełnienia wymaganej bazy wózka, która wg wymogów raportu ORE/ERRI B12/Rp14/D[6] powinna wynosić $1800 \mathrm{~mm}$. Baza wózka miała wpływ na kryterium zamienności (niem. „Austauschbarkeit”). W ten sposób do 
created for both bogies („Hüllraum”). Outside the outline of the border no part of the bogie must be sticked out, belonging to the bogie, in addition the bogie should be within the border in a static condition, being under a wagon with arranged mass of $20000 \mathrm{~kg}$. Despite the lack of standardization, for a long time this bogie was used in domestic traffic as well as it was adapted to international traffic. The 1XTa bogie has a spring suspension with leaf springs. As practice shows, the operational safety of four-axle freight wagons with 1XTa bogies largely depends on the technical condition of the leaf springs. The wagons with the above mentioned bogies have been operated on PLK S.A. lines to this day. It is worth to mention that this bogie, despite its defects, performed well in commercial operation and, which was surprisingly, it showed a susceptibility to successful modernization, as it is showed by the $1 \mathrm{XtaMp}$ bogie. The leaf spring as the essential part of the primary suspension performs three functions:

$>$ function of the elastic element, having a specific stiffness (susceptibility),

$>$ function of friction damper, which realizes its damping properties by friction between the spring leaves,

$>$ function of a load-bearing element that can transfer the certain static loads at different loading conditions of the wagons (static loads), extraordinary static loads resulting from the unusual cases occurring in the operation, the fatigue loads resulting from the dynamic work of suspension.

\section{SCOPE OF SPRING UNIFICATION}

The leaf spring used in the 1XTa bogie is a spring compatible with PN-61/K-88181 [8]. This standard defines the spring construction (leaves dimensions, spring hoop, spring wedge) as well as the acceptance criteria (unit deflection, test load and deflection under the test load).

The criteria given by the PN-61/K-88181 standard [8] are based on the formerly used unit system but correspond to the acceptance criteria in drawing 27R 070301-1-0 and they are as follows:

$$
\begin{aligned}
& >\mathrm{c}_{\mathrm{ODB}}=6,3 \pm 8 \% \mathrm{~mm} / 1 \mathrm{t}, \\
& >\mathrm{P}_{\mathrm{PRB}}=13633 \mathrm{kG}, \\
& >\mathrm{f}_{\mathrm{PR}}=86 \mathrm{~mm} \pm 8 \% .
\end{aligned}
$$

The leaf spring is marked with: LEAF SPRING 1200 PN-61/K-88181 [8].

The leaf spring is also compatible with UIC 517 [3]. This leaflet defines in very similar way the unit susceptibility of the spring as a medium deflection in the hysteresis loop of $0.66 \pm 8 \% \mathrm{~mm} / \mathrm{kN}$. The free height of the unloaded spring is defined as $212 \mathrm{~mm}$ (this dimension is given without tolerance).

The spring is in accordance with the standard drawing ERRI/UIC No 2Fwg 711.0.02.021.001 according to report ORE/ERRI B12 No.25 [7]. dalszych prac standaryzacyjnych został zakwalifikowany wózek Y25C oraz wózek DB 665. Dla obydwu wózków utworzono otoczkę (niem. „Hüllraum”). Poza zarys otoczki nie może wystawać żadna część, przynależna do wózka, przy czym wózek powinien mieścić się w otoczce w stanie statycznym, znajdującym się pod wagonem o masie umownej $20000 \mathrm{~kg}$. Mimo braku standaryzacji, wózek ten był długi czas stosowany $\mathrm{w}$ ruchu krajowym, jak również był przystosowany do ruchu międzynarodowego. Wózek 1XTa posiada usprężynowanie za pomocą resorów piórowych. Jak wykazuje praktyka eksploatacyjna, bezpieczeństwo eksploatacyjne wagonów towarowych czteroosiowych z wózkami 1XTa w poważnej mierze zależy od stanu technicznego resorów piórowych. Wagony z ww. wózkami do dnia dzisiejszego są eksploatowane na liniach PLK S.A. Warto dodać, że wózek ten pomimo swoich mankamentów, sprawdził się w eksploatacji komercyjnej oraz, co było pewnym zaskoczeniem wykazał podatność na udaną modernizację, o czym świadczy wózek 1XtaMp.Resor piórowy jako zasadnicza część zawieszenia pierwszego stopnia pełni trzy funkcje:

$>$ funkcję elementu sprężystego, mającego określoną sztywność (podatność),

$>$ funkcję thumika ciernego, które realizuje swoje własności tłumiące za pośrednictwem tarcia pomiędzy piórami resoru,

$>$ funkcję elementu nośnego, mogącego przenieść określone obciążenia statyczne $\mathrm{w}$ różnych stanach załadowania wagonów (obciążenia statyczne), nadzwyczajne obciążenia statyczne, wynikające $\mathrm{z}$ nietypowych przypadków pojawiających się $\mathrm{w}$ eksploatacji, obciążenia zmęczeniowe, wynikające z pracy dynamicznej usprężynowania.

\section{ZAKRES UNIFIKACJI RESORU}

Resor piórowy stosowany w wózku 1XTa jest resorem zgodnym z PN-61/K-88181[8]. Norma ta definiuje konstrukcję resoru (wymiary piór, opaski resorowej, klina resorowego) jak również kryteria odbiorcze (ugięcie jednostkowe, obciążenie próbne oraz ugięcie pod obciążeniem próbnym).

Kryteria, które podaje norma PN-61/K-88181[8] wynikają z dawniej stosowanego systemu jednostek, ale odpowiadają kryteriom odbiorczym na rys.27R 070301-1-0 i przedstawiają się następująco:

$$
\begin{aligned}
& >\mathrm{c}_{\mathrm{ODB}}=6,3 \pm 8 \% \mathrm{~mm} / 1 \mathrm{t}, \\
& \mathrm{P}_{\mathrm{PRB}}=13633 \mathrm{kG}, \\
& >\mathrm{f}_{\mathrm{PR}}=86 \mathrm{~mm} \pm 8 \% .
\end{aligned}
$$

\section{Resor piórowy posiada oznaczenie: RESOR}

\section{PIÓROWY 1200 PN-61/K-88181 [8].}

Resor piórowy jest zgodny również z kartą UIC 517 [3]. Karta ta definiuje w bardzo podobny sposób podatność jednostkową resoru jako ugięcie średnie $\mathrm{w}$ pętli histerezy wynoszące $0,66 \pm 8 \% \mathrm{~mm} / \mathrm{kN}$. Wysokość swobodna resoru nieobciążonego jest określona 
From this point of view, this spring is a construction approved for domestic and international traffic for two-axle freight wagons with maximum axle load on track of 20t for "S" and "SS" traffic. In the case of domestic use, its application was extended by the bogies of freight wagons such as 1XT, 1XTa and $1 \mathrm{XTa} / \mathrm{B}, 7 \mathrm{TN}$ (three-axle bogie) and 7TNa (modernized three-axle bogie 7TN). All of the above mentioned gear running systems are designed to operate with a maximum axle load of $20 \mathrm{t}$ and a maximum speed of $100 \mathrm{~km} / \mathrm{h}$. The above spring was used in the following two-axle freight wagons: $9 \mathrm{~W}, 28 \mathrm{R}, 24 \mathrm{~V}$, 28R/T, 201K, 27R, 203K, 202S, 203S, 204S, 206K and $201 \mathrm{Ka}$. These types of springs were put into service on the freight wagons of leading European boards such as DB, SNCF and NS.

\section{FACTORS INFLUENCING SOFTNESS OF SPRING}

The susceptibility tests (unit deflection) take place on the roller stand. The susceptibility tested in this way differs from that which actually occurs in suspension.

Formulas for determining the susceptibility are included in the ORE/ERRI B12 No. 25 report [7].

The above mentioned document contains 6 computational methods.

Calculation of susceptibility according to the theoretical formulas according to Appendix 1 of the ORE/ERRI B12 No. 25 report [7] and thus:

where:

$$
c_{a}=\frac{3 L^{3}}{8 \cdot n \cdot b \cdot h^{3} \cdot E}
$$

$L$ - length of the spring in expansion in [ $\mathrm{mm}$ ],

$n$ - number of leaves,

$b$ - width of leaf,

$h$-height of leaf,

$E$ - Young's modulus in $\mathrm{kN} / \mathrm{mm}^{3}$.

Assuming according to the constructional documentation and PN-61/K-88181[8], ORE/ERRI B12 Rp.25 report [7] data: $L=1200 \mathrm{~mm}, n=8, b=120 \mathrm{~mm}, h=16$ $\mathrm{mm}, \mathrm{E}=206 \mathrm{kN} / \mathrm{mm}^{2}$ and replacing into the formula (1) it is obtained:

$$
c_{a}=\frac{3 \cdot 1200^{3}}{8 \cdot 8 \cdot 120 \cdot 16^{3} \cdot 206}=0,799 \mathrm{~mm} / \mathrm{kN} .
$$

Calculation of susceptibility according to the theoretical formulas according to Appendix 1 of ORE/ERRI B12 No.25 report [7] :

$$
c_{a}=\frac{3 L^{3}}{8 \cdot\left(n-n^{*}\right) \cdot b \cdot h^{3} \cdot E}\left[1-\frac{2 \cdot n^{*}}{n-n^{*}}+\frac{2 \cdot\left(n^{*}\right)^{2}}{\left(n-n^{*}\right)^{2}} \cdot \log \frac{n}{n^{*}}\right]
$$

where:

$n^{*}=n-1-$ number of reinforcing leaves,

$n$ - number of leaves with length $\mathrm{L}$.

In this case, assuming $n=2$ it is obtained $n^{*}=1$. jako $212 \mathrm{~mm}$ (jest to wymiar podany bez tolerancji). Resor jest zgodny z rysunkiem standardowym ERRI/UIC nr 2Fwg 711.0.02.021.001 zgodnie z raportem ORE/ERRI B12 Nr.25 [7].

$\mathrm{Z}$ tego punktu widzenia resor ten jest konstrukcja dopuszczoną do ruchu wewnętrznego krajowego i międzynarodowego dla wagonów towarowych dwuosiowych o maksymalnym nacisku zestawu kołowego na tor 20t dla ruchu „S” oraz „SS”. W przypadku zastosowania krajowego jego zastosowanie zostało rozszerzone o wózki wagonów towarowych takie jak 1XT, 1XTa i 1XTa/B, 7TN (wózek trzyosiowy) i $7 \mathrm{TNa}$ (zmodernizowany wózek trzyosiowy 7TN). Wszystkie ww. układy biegowe sa przeznaczone do eksploatacji z maksymalnym naciskiem na tory wynoszącym 20t i maksymalną prędkością wynoszącą 100 $\mathrm{km} / \mathrm{h}$. Powyższy resor zastosowano w następujących dwuosiowych wagonach towarowych: $9 \mathrm{~W}, 28 \mathrm{R}, 24 \mathrm{~V}$, 28R/T, 201K, 27R, 203K, 202S, 203S, 204S, 206K i 201Ka. Resory tego typu zostały wprowadzone do eksploatacji na wagonach towarowych czołowych zarządów europejskich jak DB, SNCF i NS.

\section{CZYNNIKI WPLYWAJĄCE NA MIĘKKOŚĆ RESORU}

Badania podatności (ugięcia jednostkowego) odbywają się na stanowisku rolkowym. Podatność zbadana w ten sposób różni się od tej, która faktycznie występuje w zawieszeniu.

Wzory na wyznaczenie podatności są zawarte $\mathrm{w}$ raporcie ORE/ERRI B12 Nr. 25 [7].

Ww. dokument zawiera 6 metod obliczeniowych.

Obliczenie podatności wg wzorów teoretycznych wg zalącznika 1 raportu ORE/ERRI B12 Nr.25 [7] i tak:

gdzie:

$$
c_{a}=\frac{3 L^{3}}{8 \cdot n \cdot b \cdot h^{3} \cdot E}
$$

$L$ - długość resoru w rozwinięciu w [ $\mathrm{mm}]$,

$n$ - ilość piór,

$b$ - szerokość pióra,

$h$ - wysokość pióra,

$E$ - moduł Younga w $\mathrm{kN} / \mathrm{mm}^{3}$.

Przyjmując zgodnie $\mathrm{z}$ dokumentacją konstrukcyjną oraz PN-61/K-88181[8], raportem ORE/ERRI B12 Rp.25 [7] dane: $L=1200 \mathrm{~mm}, n=8, b=120 \mathrm{~mm}, h=16$ $\mathrm{mm}, \mathrm{E}=206 \mathrm{kN} / \mathrm{mm}^{2}$ i podstawiając do wzoru (1) otrzymuje się:

$$
c_{a}=\frac{3 \cdot 1200^{3}}{8 \cdot 8 \cdot 120 \cdot 16^{3} \cdot 206}=0,799 \mathrm{~mm} / \mathrm{kN} .
$$

Obliczenie podatności wg wzorów teoretycznych wg załącznika 1 raportu ORE/ERRI B12 Nr.25 [7] :

$$
c_{a}=\frac{3 L^{3}}{8 \cdot\left(n-n^{*}\right) \cdot b \cdot h^{3} \cdot E}\left[1-\frac{2 \cdot n^{*}}{n-n^{*}}+\frac{2 \cdot\left(n^{*}\right)^{2}}{\left(n-n^{*}\right)^{2}} \cdot \log \frac{n}{n^{*}}\right]
$$


After inserting the numerical data into formula (2) it is obtained:

$$
\begin{aligned}
& c_{a}=\frac{3 \cdot 1200^{3}}{8 \cdot(7) \cdot 120 \cdot 16^{3} \cdot 206}\left[1-\frac{2}{7}+\frac{2 \cdot(1)^{2}}{7^{2}} \cdot \log \frac{8}{1}\right]= \\
& =0,686 \mathrm{~mm} / \mathrm{kN}
\end{aligned}
$$

Calculation of susceptibility according to Kreissig's method presented in ORE/ERRI B12 No.25 report [7]:

where:

$$
c_{a}=\frac{6 \cdot \frac{F}{2} \cdot l^{3}}{b \cdot h^{3} \cdot E \cdot\left(n+\frac{n^{*}}{2}\right)}
$$

is $1=600 \mathrm{~mm}$.

After inserting the numerical data into formula (5) it is obtained:

$$
c_{a}=\frac{6 \cdot 0.5 \cdot 600^{3}}{120 \cdot 16^{3} \cdot 206 \cdot\left(8+\frac{1}{2}\right)}=0.752 \mathrm{~mm} / \mathrm{kN}
$$

Calculation of susceptibility according to Hütte's method presented in ORE/ERRI B12 No.25 report [7]:

$$
c_{a}=\frac{L^{3}}{16 \cdot\left(2+\frac{n}{n^{\prime}}\right) \cdot E \cdot J \cdot n} \cdot k
$$

where:

$$
n=2 \text {, }
$$

$\mathrm{k}$ - coefficient presented in table 2 ,

$J$ - moment of inertia of one spring leaf; for rectangular section it is $J=\frac{120 \cdot 16^{3}}{12}=40960 \mathrm{~mm}^{4}$

Dependence of the coefficient $k$ on the ratio $\left(\frac{n}{n^{\prime}}\right)$ gdzie:

$n^{*}=n-1-$ ilość piór wzmacniających, $n$ - ilość piór o długości L.

$\mathrm{W}$ tym przypadku przyjmując $\mathrm{n}^{\prime}=2$ otrzymuje się $\mathrm{n}^{*}=1$. Po wstawieniu danych liczbowych do wzoru (2) otrzymuje się:

$$
\begin{aligned}
& c_{a}=\frac{3 \cdot 1200^{3}}{8 \cdot(7) \cdot 120 \cdot 16^{3} \cdot 206}\left[1-\frac{2}{7}+\frac{2 \cdot(1)^{2}}{7^{2}} \cdot \log \frac{8}{1}\right]= \\
& =0,686 \mathrm{~mm} / \mathrm{kN}
\end{aligned}
$$

Obliczenie podatności wg metody Kreissiga przedstawionej w raporcie ORE/ERRI B12 Nr.25 [7]:

$$
c_{a}=\frac{6 \cdot \frac{F}{2} \cdot l^{3}}{b \cdot h^{3} \cdot E \cdot\left(n+\frac{n^{*}}{2}\right)}
$$

gdzie:

1-połowa długości resoru, wynosząca w tym przypadku $\mathrm{l}=600 \mathrm{~mm}$.

Po wstawieniu danych liczbowych do wzoru (5) otrzymuje się:

$$
c_{a}=\frac{6 \cdot 0.5 \cdot 600^{3}}{120 \cdot 16^{3} \cdot 206 \cdot\left(8+\frac{1}{2}\right)}=0.752 \mathrm{~mm} / \mathrm{kN}
$$

gdzie:

Obliczenie podatności wg metody Hüttego przedstawionej w raporcie ORE/ERRI B12 Nr.25 [7]:

$$
c_{a}=\frac{L^{3}}{16 \cdot\left(2+\frac{n}{n^{\prime}}\right) \cdot E \cdot J \cdot n} \cdot k
$$

$$
n '=2 \text {, }
$$

k- współczynnik przedstawiony w tablicy 2 , $J$ - moment bezwładności jednego pióra resoru; dla przekroju prostokątnego wynosi on $J=\frac{120 \cdot 16^{3}}{12}=40960 \mathrm{~mm}^{4}$

Zależność współczynnika k od stosunku $\left(\frac{n}{n^{\prime}}\right)$

Tablica 2/Table 2

\begin{tabular}{|c|c|c|c|c|c|c|c|c|c|c|c|}
\hline$\left(\frac{n^{\prime}}{n}\right)$ & 0,1 & 0,15 & 0,2 & 0,3 & 0,4 & 0,5 & 0,6 & 0,7 & 0,8 & 0,9 & 1,0 \\
\hline $\mathrm{k}$ & 0,981 & 0,971 & 0,966 & 0,962 & 0,964 & 0,967 & 0,971 & 0,977 & 0,983 & 0,991 & 1,0 \\
\hline
\end{tabular}

In the given case $\left(\frac{n^{\prime}}{n}=\frac{2}{8}=0,25\right)$ the coefficient $\mathrm{k}=0,964 \quad \mathrm{~W}$ podanym przypadku $\left(\frac{n^{\prime}}{n}=\frac{2}{8}=0,25\right)$ współczynnik (interpolated value).

$\mathrm{k}=0,964$ (wartość interpolowana).

Inserting the numerical data into formula (7) it is ob- Podstawiając dane liczbowe do wzoru (7) otrzymuje tained: się:

$c_{a}=\frac{1200^{3}}{16 \cdot(2+0,25) \cdot 206 \cdot 40960 \cdot 8} \cdot 0,964=0,685 \mathrm{~mm} / \mathrm{kN}$ 
Calculation of susceptibility according to Dubbel's method presented in ORE/ERRI B12 No. 25 report [7]:

where:

$$
c_{a}=4 \cdot \psi \frac{l^{3} \cdot \frac{F}{2}}{n \cdot b \cdot h^{3} \cdot E}
$$

$\psi$ - coefficient dependent on ratio $\left(\frac{n^{\prime}}{n}\right)$, and

its numerical values are shown in Table 3 .

After inserting the numerical data and coefficient $\psi=1,283$ (interpolated value) (9) it is obtained:

$$
c_{a}=4 \cdot 1,283 \frac{600^{3} \cdot 0.5}{8 \cdot 120 \cdot 16^{3} \cdot 206}=0,684
$$

Calculation of susceptibility according to Gross' method presented in ORE/ERRI B12 No. 25 report [7]:

$$
c_{a}=\frac{4 \cdot K \cdot l^{3} \cdot \frac{F}{2}}{n \cdot b \cdot h^{3} \cdot E}
$$

where:

$$
\text { K- coefficient identical to } \psi \text {. }
$$

After inserting the numerical data into formula (11) it is obtained:

$$
c_{a}=\frac{4 \cdot 1,283 \cdot 600^{3} \cdot 0,5}{8 \cdot 120 \cdot 16^{3} \cdot 206}=0,684 \mathrm{~mm} / \mathrm{kN}
$$

Calculation of susceptibility according to BR (British Railway) method presented in ORE/ERRI B12 No. 25 report [7]:

$$
c_{a}=\frac{L^{3}}{3312\left(2+\frac{n^{\prime}}{n}\right) \cdot \frac{n \cdot b \cdot h^{3}}{12} \cdot 10^{3}}
$$

After inserting the numerical values of the spring dimensions in $\mathrm{mm}$ into formula (13) factor $10^{3}$ is omitted in the denominator and it is obtained:

$$
c_{a}=\frac{1200^{3}}{3312 \cdot\left(2+\frac{2}{8}\right) \cdot \frac{8 \cdot 120 \cdot 16^{3}}{12}}=0,707 \mathrm{~mm} / \mathrm{kN}
$$

Calculation of susceptibility according to DB (Deutsche Bahn) method presented in ORE/ERRI B12 No. 25 report [7]:

$$
c_{a}=\frac{l^{3} \cdot 12}{2 \cdot\left(2+\frac{n^{\prime}}{n}\right) \cdot E \cdot n \cdot b \cdot h^{3}}
$$

Obliczenie podatności wg metody Dubbela przedstawionej w raporcie ORE/ERRI B12 Nr. 25 [7]:

$$
c_{a}=4 \cdot \psi \frac{l^{3} \cdot \frac{F}{2}}{n \cdot b \cdot h^{3} \cdot E}
$$

gdzie:

$\psi$ - współczynnik zależny od stosunku $\left(\frac{n^{\prime}}{n}\right)$, a

jego wartości liczbowe są przedstawione $\mathrm{w}$ tablicy 3.

Po wstawieniu danych liczbowych i współczynnika $\psi=1,283$ ( wartość interpolowana) (9) otrzymuje się:

$$
c_{a}=4 \cdot 1,283 \frac{600^{3} \cdot 0.5}{8 \cdot 120 \cdot 16^{3} \cdot 206}=0,684
$$

Obliczenie podatności wg metody Grossa przedstawionej w raporcie ORE/ERRI B12 Nr. 25 [7]:

$$
c_{a}=\frac{4 \cdot K \cdot l^{3} \cdot \frac{F}{2}}{n \cdot b \cdot h^{3} \cdot E}
$$

gdzie:

K- współczynnik identyczny jak $\psi$.

Po wstawieniu danych liczbowych do wzoru (11) otrzymuje się:

$$
c_{a}=\frac{4 \cdot 1,283 \cdot 600^{3} \cdot 0,5}{8 \cdot 120 \cdot 16^{3} \cdot 206}=0,684 \mathrm{~mm} / \mathrm{kN}
$$

Obliczenie podatności wg metody BR (British Railway) przedstawionej w raporcie ORE/ERRI B12 Nr. 25 [7]:

$$
c_{a}=\frac{L^{3}}{3312\left(2+\frac{n^{\prime}}{n}\right) \cdot \frac{n \cdot b \cdot h^{3}}{12} \cdot 10^{3}}
$$

\begin{tabular}{|c|c|c|c|c|c|c|c|c|c|c|c|}
\hline \multicolumn{4}{|c|}{ Zależność współczynnika $\psi$ od stosunku } & & \multicolumn{4}{|c|}{ Dependence of the coefficient $\psi$ on the ratio } & $\mathbf{0}\left(n^{\prime}\right)$ & \multicolumn{2}{|c|}{ Tablica 3/Table } \\
\hline$\left(\frac{n}{n}\right)$ & 0 & 0,1 & 0,2 & 0,3 & 0,4 & 0,5 & 0,6 & 0,7 & 0,8 & 0,9 & 1,0 \\
\hline$\psi$ & 1,500 & 1,390 & 1,315 & 1,250 & 1,202 & 1,160 & 1,121 & 1,085 & 1,054 & 1,025 & 1,0 \\
\hline
\end{tabular}

Po wstawieniu wartości liczbowych wymiarów reso$\mathrm{ru}$ wyrażonych $\mathrm{w} \mathrm{mm}$ do wzoru (13) pomija się czynnik $10^{3}$ w mianowniku i otrzymuje się:

$$
c_{a}=\frac{1200^{3}}{3312 \cdot\left(2+\frac{2}{8}\right) \cdot \frac{8 \cdot 120 \cdot 16^{3}}{12}}=0,707 \mathrm{~mm} / \mathrm{kN}
$$

Obliczenie podatności wg metody DB (Deutsche Bahn), przedstawionej w raporcie ORE/ERRI B12 Nr. 25 [7]:

$$
c_{a}=\frac{l^{3} \cdot 12}{2 \cdot\left(2+\frac{n^{\prime}}{n}\right) \cdot E \cdot n \cdot b \cdot h^{3}}
$$


After inserting the numerical values into formula (15) it is obtained:

$$
c_{a}=\frac{600^{3} \cdot 12}{2 \cdot\left(2+\frac{2}{8}\right) \cdot 206 \cdot 8 \cdot 120 \cdot 16^{3}}=0,711 \mathrm{~mm} / \mathrm{kN}
$$

Calculation of susceptibility according to SNCF (French Railways) method presented in ORE/ERRI B12 No. 25 report [7]:

$$
c_{a}=\frac{L_{u}^{3}}{50 \cdot\left(n+n^{*}\right) \cdot b \cdot h^{3}}
$$

where:

$$
\begin{aligned}
& \mathrm{L}_{\mathrm{u}}=\mathrm{L}-\mathrm{e}+20=1200-100+20=1120 \mathrm{~mm} \\
& \text { e- width of the spring hoop }(\mathrm{e}=100 \mathrm{~mm}) .
\end{aligned}
$$

After inserting the numerical values into formula (17) it is obtained:

$$
c_{a}=\frac{1120^{3}}{50 \cdot(8+1) \cdot 120 \cdot 16^{3}}=6,35 \mathrm{~mm} / \mathrm{Mp}=0,635 \mathrm{~mm} / \mathrm{kN}
$$

Calculation of susceptibility according to NS (Dutch Railways) method presented in ORE/ERRI B12 No. 25 report[7]:

$$
c_{a}=\frac{2 k}{n} \cdot \frac{F \cdot l^{3}}{E \cdot b \cdot h^{3}}
$$

where:

$$
k=\frac{3,5}{2,5+\frac{n_{1}}{n}} \text { jeśli } \frac{n^{\prime}}{n} \geq 0,2 \text { and } n_{1}=\frac{\sum L_{n}}{\frac{1}{2} \cdot L}-n
$$

After inserting the numerical values into formula (19) it is obtained:

$c_{a}=\frac{2 \cdot 1.21}{8} \cdot \frac{600^{3}}{206 \cdot 120 \cdot 16^{3}}=0,645 \mathrm{~mm} / \mathrm{kN} \cong 0,65$

$$
\begin{aligned}
& \text { where the coefficient } k=\frac{3,5}{2,5+\frac{3,15}{8}}=1,21 \text { and } \\
& n_{1}=\frac{1200+1200+1140+970+800+630+460+290}{600}-8=3,15
\end{aligned}
$$

A list of the individual results of susceptibility calculated based on the different computational methods is presented in Table 4.
Po wstawieniu wartości liczbowych do wzoru (15) otrzymuje się:

$$
c_{a}=\frac{600^{3} \cdot 12}{2 \cdot\left(2+\frac{2}{8}\right) \cdot 206 \cdot 8 \cdot 120 \cdot 16^{3}}=0,711 \mathrm{~mm} / \mathrm{kN}
$$

Obliczenie podatności wg metody SNCF (koleje francuskie) przedstawionej w raporcie ORE/ERRI B12 Nr. 25 [7]:

$$
c_{a}=\frac{L_{u}^{3}}{50 \cdot\left(n+n^{*}\right) \cdot b \cdot h^{3}}
$$

gdzie:

$$
\begin{aligned}
& \mathrm{L}_{\mathrm{u}}=\mathrm{L}-\mathrm{e}+20=1200-100+20=1120 \mathrm{~mm} \\
& \text { e- szerokość opaski resorowej }(\mathrm{e}=100 \mathrm{~mm}) .
\end{aligned}
$$

Po wstawieniu wartości liczbowych do wzoru (17) otrzymuje się:

$c_{a}=\frac{1120^{3}}{50 \cdot(8+1) \cdot 120 \cdot 16^{3}}=6,35 \mathrm{~mm} / \mathrm{Mp}=0,635 \mathrm{~mm} / \mathrm{kN}$

Obliczenie podatności wg metody NS (koleje holenderskie) przedstawionej $\mathrm{w}$ raporcie ORE/ERRI B12 Nr. 25 [7]:

$$
c_{a}=\frac{2 k}{n} \cdot \frac{F \cdot l^{3}}{E \cdot b \cdot h^{3}}
$$

\begin{tabular}{|c|c|c|c|c|c|c|c|c|c|c|}
\hline $\begin{array}{l}\text { Opis metody/ Descrip- } \\
\text { tion of method }\end{array}$ & \begin{tabular}{l|} 
wg \\
zal.1[7]/ \\
acc to \\
annex \\
$1[7]$ \\
\end{tabular} & $\begin{array}{l}\text { wg } \\
\text { zal.1[7]/ } \\
\text { acc to } \\
\text { annex } \\
1[7] \\
\end{array}$ & $\begin{array}{c}\text { wg } \\
\text { Kreissi- } \\
\text { ga/ acc } \\
\text { to Kre- } \\
\text { issig } \\
\end{array}$ & $\begin{array}{c}\text { wg } \\
\text { Hüttego/ } \\
\text { acc to } \\
\text { Hütte }\end{array}$ & $\begin{array}{c}\text { wg } \\
\text { Dubbela/ } \\
\text { acc to } \\
\text { Dubbel }\end{array}$ & $\begin{array}{l}\text { wg } \\
\text { Grossa/ } \\
\text { acc to } \\
\text { Gross }\end{array}$ & $\begin{array}{l}\text { wg } \\
\text { BR/ } \\
\text { acc to } \\
\text { BR }\end{array}$ & $\begin{array}{l}\text { wg } \\
\text { DB/ } \\
\text { acc to } \\
\text { DB }\end{array}$ & $\begin{array}{l}\text { wg } \\
\text { SNCF/ } \\
\text { acc to } \\
\text { SNCF }\end{array}$ & \begin{tabular}{|l|} 
wg \\
NS/ \\
acc \\
to \\
NS \\
\end{tabular} \\
\hline $\begin{array}{l}\text { Podatność/ Susceptibili- } \\
\text { ty } \\
{[\mathrm{mm} / \mathbf{k N}]}\end{array}$ & 0,799 & 0,686 & 0,752 & 0,685 & 0,684 & 0,684 & 0,707 & 0,711 & 0,635 & 0,65 \\
\hline $\begin{array}{l}\text { Podatność } \mathrm{m} / \mathrm{kN}] \\
\text { wg karty UIC 517/ } \\
\text { Susceptibility }[\mathrm{mm} / \mathrm{kN}] \\
\text { acc to UIC } 517\end{array}$ & \multicolumn{10}{|c|}{$0,66 \pm 0,0528$} \\
\hline $\begin{array}{l}\text { Podatność }[\mathrm{mm} / \mathrm{kN}] \text { wg } \\
\text { rys./Susceptibility } \\
{[\mathrm{mm} / \mathrm{kN}] \text { acc to drawing }}\end{array}$ & \multicolumn{10}{|c|}{$0,64 \pm 0,0512$} \\
\hline
\end{tabular}

gdzie:

$$
k=\frac{3,5}{2,5+\frac{n_{1}}{n}} \text { jeśli } \frac{n^{\prime}}{n} \geq 0,2 \text { oraz } n_{1}=\frac{\sum L_{n}}{\frac{1}{2} \cdot L}-n
$$

Po wstawieniu danych liczbowych do wzoru (19) otrzymuje się:

$$
c_{a}=\frac{2 \cdot 1.21}{8} \cdot \frac{600^{3}}{206 \cdot 120 \cdot 16^{3}}=0,645 \mathrm{~mm} / \mathrm{kN} \cong 0,65
$$

gdzie współczynnik $k=\frac{3,5}{2,5+\frac{3,15}{8}}=1,21$ oraz

$n_{1}=\frac{1200+1200+1140+970+800+630+460+290}{600}-8=3,15$

Zestawienie poszczególnych wyników podatności wyliczonych na podstawie różnych metod obliczeniowych przedstawiono w tablicy 4.

Zestawienie wyników podatności resorów wyliczonych na podstawie różnych metod obliczeniowych

List of the results of springs susceptibility calculated based on the different computational methods Tablica 4/Table 4 
According to the presented analysis, the most similar values to the required and presented in the construction documentation, the PN-61/K-88181 standard [8] and the UIC 517 leaflet [3], is the method used by the SNCF and NS railways. Both of these methods give the difference in nominal values of susceptibility presented in UIC 517 [3] and PN-61/K-88181 [8] by $1.81 \%$ and $1.56 \%$, respectively. In the further part of analysis, the NS method will be referred to as providing the closest results to the values required by the constructional documentation and standards.

\section{REASONS OF SPRING SUSCEPTIBILITY REDUCTION}

Susceptibility of spring calculated according to the above formulas is a nominal susceptibility. In the case of new springs, the tolerance of susceptibility is due to the geometrical deviations of the individual spring leaves.

Assuming according to drawing 27R 070301-1-0 and UIC 820 leaflet [4] the executive deviations:

$L=1200_{-3}^{+3} \quad \mathrm{~mm}$ (and therefore $l=600_{-1,5}^{+1,5} \mathrm{~mm}$ ), $b=120_{-0,5}^{+0,5} \mathrm{~mm}, h=16_{-0,2}^{+0,2} \mathrm{~mm}$ are calculated below the maximum and minimum susceptibility of the spring respectively.

Thus the maximum susceptibility determined according to (19) is:

$$
c_{\text {aMAX }}=\frac{2 \cdot 1.21}{8} \cdot \frac{601,5^{3}}{206 \cdot 119,5 \cdot 15,8^{3}}=0,667 \mathrm{~mm} / \mathrm{kN}
$$

Minimalna podatność wyliczona na podstawie wzoru (19) wynosi:

The minimum susceptibility calculated by formula (19) is:

$$
c_{\text {aMIN }}=\frac{2 \cdot 1.21}{8} \cdot \frac{598,5^{3}}{206 \cdot 120,5 \cdot 16,2^{3}}=0,6144 \mathrm{~mm} / \mathrm{kN}
$$

In connection with above it can be found that the value of spring susceptibility in the new state is in the following range:

$$
c_{a}=0,645_{-0,0306}^{+0,022} \mathrm{~mm} / \mathrm{kN}
$$

that is the maximum susceptibility differs by $3.89 \%$ from the nominal value and the minimum susceptibility differs by $4.744 \%$ from the nominal value. From this it can be concluded that the tolerance of susceptibility $\pm 8 \%$ provided in the constructional documentation and PN-61/ K-88181 [8], UIC 517 leaflet [3] and UIC 821 leaflet [5] is correct.

The calculated deviations from the nominal susceptibility in formulas (21), (22) and (23) have the maximal character, taking into account their unfavorable distribution. Assuming that the deviations of all dimensions are in accordance with the Gaussian distribution, then the susceptibility of $c_{\text {aSTAT }}$ can be determined from the dependence:
W związku z powyższym można stwierdzić, że wartość podatności resoru w stanie nowym znajduje się w następującym zakresie:

$$
c_{a}=0,645_{-0,0306}^{+0,022} \mathrm{~mm} / \mathrm{kN}
$$

czyli maksymalna podatność różni się o 3,89\% od wartości nominalnej oraz minimalna podatność różni się o $4,744 \%$ od wartości nominalnej. $Z$ tego można wyciagnąć wniosek, że tolerancja podatności $\pm 8 \%$ przewidziana w dokumentacji konstrukcyjnej oraz PN61/K-88181 [8], karcie UIC 517 [3] i karcie UIC 821 [5] jest prawidłowa.

Wyliczone odchyłki od podatności nominalnej we wzorach (21), (22) oraz (23) mają charakter maksymalny, biorąc pod uwage ich niekorzystny rozkład. Zakładając, że odchyłki wszystkich wymiarów mają charakter zgodny z rozkładem Gaussa wówczas podatność $c_{\text {aSTAT }}$ można wyznaczyć z zależności: 


$$
\begin{gathered}
c_{a S T A T}=c_{a} \pm \frac{1}{2} \sqrt{\left(\frac{\partial c_{a}}{\partial l} \cdot \Delta l\right)^{2}+\left(\frac{\partial c_{a}}{\partial b} \cdot \Delta b\right)^{2}+\left(\frac{\partial c_{a}}{\partial h} \cdot \Delta h\right)^{2}} \\
c_{a S T A T}=c_{a} \pm \frac{1}{2} \sqrt{\left(\frac{6 k}{n} \cdot \frac{l^{2}}{E \cdot b \cdot h^{3}} \Delta l\right)^{2}+\left(-\frac{2 k}{n} \cdot \frac{l^{3}}{E \cdot b^{2} \cdot h^{3}} \cdot \Delta b\right)^{2}+\left(-\frac{6 k}{n} \frac{l^{3}}{E \cdot b^{2} \cdot h^{4}} \cdot \Delta h\right)^{2}}
\end{gathered}
$$

Calculating the component factors it is determined:

$$
\begin{aligned}
& \left(\frac{\partial c_{a S T A T}}{\partial l} \cdot \Delta l\right)^{2}=\left(\frac{6 k}{n} \cdot \frac{l^{2}}{E \cdot b \cdot h^{3}} \cdot \Delta l\right)^{2}=2,342415636 \cdot 10^{-5} \\
& \left(\frac{\partial c_{a S T A T}}{\partial b} \cdot \Delta b\right)^{2}=\left(-\frac{2 k}{n} \cdot \frac{l^{3}}{E \cdot b^{2} \cdot h^{3}} \cdot \Delta b\right)^{2}=7,2296677889 \cdot 10^{-6} \\
& \left(\frac{\partial c_{a S T A T}}{\partial h} \cdot \Delta h\right)^{2}=\left(-\frac{6 k}{n} \cdot \frac{l^{3}}{E \cdot b \cdot h^{4}} \cdot \Delta h\right)^{2}=5,856039087 \cdot 10^{-4} \\
& \text { caSTAT }_{\text {aST }}=0,645 \pm 0,012 \mathrm{~mm} / \mathrm{kN}
\end{aligned}
$$

A difference of $\pm 1.86 \%$ relative to the nominal value results from the formula (29).

Dependence (24) applies to keeping of condition that the deviations of component dimensions of the spring are symmetrical in relation to the average value.

The following values result from the formula (29):

$>$ maximum statistical deviation: $\mathrm{c}_{\text {aSTATMAX }}=0,657 \mathrm{~mm} / \mathrm{kN}$

minimum statistical deviation: $\mathrm{c}_{\text {aSTATMIN }}=0,633 \mathrm{~mm} / \mathrm{kN}$

The analysis assumes that the value of Young's modulus is constant.

Based on the previous part of the analysis, it can be concluded that the executive deviations of the springs in the new condition do not cause a spread of susceptibility exceeding the acceptable range defined by the rules i.e.. $\pm 8 \%$.

Loss of spring characteristics is a phenomenon occurring in operation and it results from the several factors:

$>$ wear of spring leaves,

$>$ disappearance of lubricant used between the spring leaves,

$>$ corrosion consisting in the formation of iron oxides.

According to the ORE/ERRI B12 Bericht No.25 report [7] the German railways DB carried out the tests for 100 pieces of 8-leaf springs $120 \times 16-1200 \mathrm{~mm}$. The characteristics of all springs, which at various periods were in operation, were determined after the dismantling from gear running systems on the freight wagons. Histograms were made on the basis of the obtained results. The tests of characteristics were carried out in two load ranges i.e.:

$>$ tests in the range between $20 \mathrm{kN}$ and $70 \mathrm{kN}$ and

$>$ tests in the range between $20 \mathrm{kN}$ and $90 \mathrm{kN}$.
Ze wzoru (29) wynika różnica wynosząca $\pm 1,86 \%$ w stosunku do wartości nominalnej.

Zależność (24) obowiązuje przy zachowaniu warunku, że odchyłki wymiarów składowych resoru mają charakter symetryczny w stosunku do wartości średniej. Ze wzoru (29) wynikają następujące wartości:

$>$ maksymalna odchyłka statystyczna:

$$
\mathrm{c}_{\text {aSTATMAX }}=0,657 \mathrm{~mm} / \mathrm{kN}
$$

$>$ minimalna odchyłka statystyczna:

$$
c_{\text {aSTATMIN }}=0,633 \mathrm{~mm} / \mathrm{kN}
$$

W analizie przyjęto, że wartość modułu Younga ma stałą wartość.

$\mathrm{Na}$ podstawie dotychczasowej części analizy można wyciagnąć wniosek, że odchyłki wykonawcze resorów w stanie nowym nie są przyczyną rozrzutu podatności wykraczającego poza dopuszczalny zakres określony przepisami tzn. $\pm 8 \%$.

Utrata charakterystyki resoru jest zjawiskiem spotykanym w eksploatacji i wynika z kilku czynników:

$>$ zużycia piór resorowych,

$>$ zaniku smaru stosowanego pomiędzy piórami resorowymi,

$>$ korozji, polegającej na powstawaniu tlenków żelaza.

Jak wynika z raportu ORE/ERRI B12 Bericht Nr.25 [7] koleje niemieckie DB przeprowadziły badania na 100 sztukach resorów 8 piórowych $120 \times 16-1200 \mathrm{~mm}$. Charakterystyki wszystkich resorów, które w różnych okresach były w eksploatacji, zostały ustalone po demontażu z układów biegowych na wagonach towarowych. Na podstawie otrzymanych wyników sporządzono histogramy. Badania charakterystyk przeprowadzono w dwóch zakresach obciążeń tzn.:

$>$ badania w zakresie pomiędzy $20 \mathrm{kN}$ oraz 70 $\mathrm{kN}$ oraz

$>$ badania $\mathrm{w}$ zakresie pomiędzy $20 \mathrm{kN}$ oraz 90 $\mathrm{kN}$. 
It turns out that the range of interchangeability of measured susceptibilities in the range of forces between $20 \mathrm{kN}$ and $70 \mathrm{kN}$ is relatively large and is:

$$
\begin{aligned}
c_{a 7 \max } & =0,805 \mathrm{~mm} / \mathrm{kN} \\
c_{\text {a } \min } & =0,591 \mathrm{~mm} / \mathrm{kN}
\end{aligned}
$$

Bringing it to the values that apply to the new spring:

$$
c_{a 7}=0,645_{-0,054}^{+0,160} \mathrm{~mm} / \mathrm{kN}
$$

In calculations in percentage of deviations it is obtained:

$$
c_{a 7}=0,645_{-8 \%}^{+24 \%} \mathrm{~mm} / \mathrm{kN}
$$

The range of variability of the measured susceptibilities in the range of forces between $20 \mathrm{kN}$ and $90 \mathrm{kN}$ is different and it is as follows:

$$
\begin{gathered}
c_{a 9 \max }=0,703 \mathrm{~mm} / \mathrm{kN} \\
c_{a 7 \min }=0,510 \mathrm{~mm} / \mathrm{kN}
\end{gathered}
$$

Bringing it to the values that apply to the new spring:

$$
c_{a 9}=0,645_{-0,130}^{+0,058} \mathrm{~mm} / \mathrm{kN}
$$

In calculations in percentage of deviations it is obtained:

$$
c_{a 9}=0,645_{-20,93 \%}^{+8,99 \%} \mathrm{~mm} / \mathrm{kN}
$$

The mean value of the measured susceptibilities in the range of forces between $20 \mathrm{kN}$ and $70 \mathrm{kN}$ is:

$$
c_{\text {aSREDNIE-70 }}=\frac{0,805+0,591}{2}=0,698 \mathrm{~mm} / \mathrm{kN}
$$

The mean value of the measured susceptibilities in the range of forces between $20 \mathrm{kN}$ and $90 \mathrm{kN}$ is:

$$
c_{\text {aSREDNIE-90 }}=\frac{0,703+0,510}{2}=0,6065 \mathrm{~mm} / \mathrm{kN}
$$

Based on this part of the analysis, it can be concluded that the change of susceptibility is a normal phenomenon and it is encountered on other railway management boards.

The differences occurred after some period of exploitation should be explained by the following phenomena:

$>$ wear of the spring part (reduction of the thickness of the spring leaves),

$>$ increased friction (hysteresis) between the spring leaves.

As there is friction between the leaves of spring, it may be concluded that there are at least three types of susceptibility (fig.1):

$>$ average susceptibility resulting from the load graph $\mathrm{c}_{\mathrm{a}}$,

$>$ susceptibility at the increasing load $\mathrm{c}_{\mathrm{b}}$,

$>$ susceptibility at the decreasing $\operatorname{load} \mathrm{c}_{\mathrm{c}}$.

According to the ORE/ERRI B12 Rp.25 report [7] the ratio $\frac{c_{b}}{c_{a}}$ is as follows:

$>$ for new springs $\frac{c_{b}}{c_{a}}=0,95$,
Okazuje się, że zakres zamienności zmierzonych podatności w zakresie sil pomiędzy $20 \mathrm{kN}$ i $70 \mathrm{kN}$ jest względnie duży i wynosi:

$$
\begin{aligned}
c_{a 7 \max } & =0,805 \mathrm{~mm} / \mathrm{kN} \\
c_{a 7 \min } & =0,591 \mathrm{~mm} / \mathrm{kN}
\end{aligned}
$$

Sprowadzając to do wartości jakie obowiązują przy nowym resorze:

$$
c_{a 7}=0,645_{-0,054}^{+0,160} \quad \mathrm{~mm} / \mathrm{kN}
$$

W przeliczeniu na procentowy udział odchyłek otrzymuje się:

$$
c_{a 7}=0,645_{-8 \%}^{+24 \%}
$$

Zakres zmienności zmierzonych podatności w zakresie sił pomiędzy $20 \mathrm{kN}$ i $90 \mathrm{kN}$ ma inny charakter i przedstawia się następująco:

$$
\begin{aligned}
& c_{a 9 \max }=0,703 \mathrm{~mm} / \mathrm{kN} \\
& c_{a 7 \min }=0,510 \mathrm{~mm} / \mathrm{kN}
\end{aligned}
$$

Sprowadzając to do wartości jakie obowiązuja przy nowym resorze:

$$
c_{a 9}=0,645_{-0,130}^{+0,058} \quad \mathrm{~mm} / \mathrm{kN}
$$

W przeliczeniu na procentowy udział odchyłek otrzymuje się:

$$
c_{a 9}=0,645_{-20,93 \%}^{+8,99 \%} \quad \mathrm{~mm} / \mathrm{kN}
$$

Wartość średnia zakresu zmierzonych podatności $\mathrm{w}$ zakresie sił pomiędzy $20 \mathbf{~ k N ~ i ~} 70 \mathbf{~ k N}$ wynosi:

$$
c_{\text {aSREDNIE-70 }}=\frac{0,805+0,591}{2}=0,698 \mathrm{~mm} / \mathrm{kN}
$$

Wartość średnia zakresu zmierzonych podatności w zakresie sił pomiędzy $20 \mathrm{kN} \mathrm{i} 90 \mathrm{kN}$ wynosi:

$$
c_{\text {aSREDNIE-90 }}=\frac{0,703+0,510}{2}=0,6065 \mathrm{~mm} / \mathrm{kN}
$$

Na podstawie tej części analizy można wnioskować, że zmiana podatności jest zjawiskiem normalnym i spotykanym na innych zarządach kolejowych.

Występujące różnice po pewnym okresie eksploatacji należy thumaczyć następującymi zjawiskami:

$>$ zużyciem części resoru (zmniejszenie grubości piór resorowych),

$>$ zwiększonym tarciem (histerezą) pomiędzy piórami resorowymi.

Ponieważ pomiędzy piórami resoru występuje tarcie można wnioskować, że istnieją co najmniej trzy rodzaje podatności (rys.1):

$>$ podatność średnia wynikająca z wykresu obciążenia $\mathrm{c}_{\mathrm{a}}$,

$>$ podatność przy wzrastającym obciążeniu $\mathrm{c}_{\mathrm{b}}$,

$>$ podatność przy zmniejszającym się obciążeniu $\mathrm{c}_{\mathrm{c}}$.

Jak wynika z raportu ORE/ERRI B12 Rp.25 [7] stosunek $\frac{c_{b}}{c_{a}}$ przedstawia się następująco:

$>$ dla nowych resorów $\frac{c_{b}}{c_{a}}=0,95$, 
for lubricated springs $\frac{c_{b}}{c_{a}}=0,92 \div 0,96$,

$>$ for non-lubricated and worn springs $\frac{c_{b}}{c_{a}}=0,85 \div 0,87$.

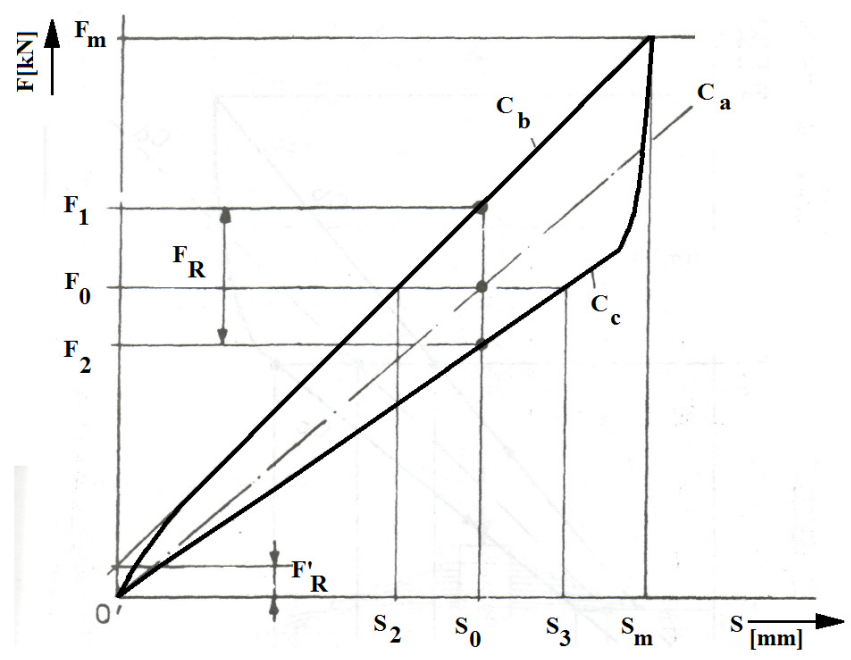

Rys.1. Wykres zależności pomiędzy obciążeniem i ugięciem resoru

Fig.1. Graph of dependence between load and spring deflection

These proportions were developed on the basis of many years operational tests carried out on the European railway management boards such as $\mathrm{DB}, \mathrm{SNCF}$ and NS in the 1970s and 1980s. Therefore, it can be concluded that if $\mathrm{c}_{\mathrm{a}}=0,642 \mathrm{~mm} / \mathrm{kN}$ then the unit susceptibility at the increasing load (that is as the accep-

Zestawienie podatności resorów pomierzonych przez różne zarządy kolejowe na stanowisku rolkowym (resory w stanie nowym)

List of susceptibility of springs measured by different railway management boards on the roller stand (springs in the new state)

\begin{tabular}{|c|c|c|c|c|c|c|c|c|}
\hline \multicolumn{9}{|c|}{$\begin{array}{c}\text { Badania resoru zamontowanego na stanowisku rolkowym/ } \\
\text { Tests of the spring mounted on the roller stand }\end{array}$} \\
\hline \multirow{2}{*}{$\begin{array}{l}\text { Producent } \\
\text { dla kolei/ } \\
\text { Producer } \\
\text { for railway }\end{array}$} & \multirow{2}{*}{$\begin{array}{c}\text { Rodzaj } \\
\text { Podatności/Kind } \\
\text { of susceptibility }\end{array}$} & \multirow{2}{*}{ SNCF } & \multirow{2}{*}{ NS } & \multirow{2}{*}{ DB } & \multirow{2}{*}{$\begin{array}{c}\text { Wartość } \\
\text { średnia/Average } \\
\text { value }\end{array}$} & \multicolumn{3}{|c|}{$\begin{array}{c}\text { Wskaźnik/Index } \\
\frac{c_{b}}{c_{a}}\end{array}$} \\
\hline & & & & & & SNCF & FS & DB \\
\hline \multirow[b]{2}{*}{ SNCF } & $\mathrm{c}_{\mathrm{a}}[\mathrm{kN} / \mathrm{mm}]$ & 0,663 & 0,677 & 0,663 & 0,668 & \multirow[b]{2}{*}{0,93} & \multirow[b]{2}{*}{0,96} & \multirow[b]{2}{*}{0,95} \\
\hline & $\begin{array}{c}\mathrm{c}_{\mathrm{b}} \\
{[\mathrm{kN} / \mathrm{mm}]}\end{array}$ & 0,623 & 0,641 & 0,626 & 0,63 & & & \\
\hline \multirow{2}{*}{ NS } & $\begin{array}{c}\mathrm{c}_{\mathrm{a}} \\
{[\mathrm{kN} / \mathrm{mm}]}\end{array}$ & 0,667 & 0,67 & 0,67 & 0,669 & \multirow[b]{2}{*}{0,96} & \multirow[b]{2}{*}{0,93} & \\
\hline & $\begin{array}{c}\mathrm{c}_{\mathrm{b}} \\
{[\mathrm{kN} / \mathrm{mm}]}\end{array}$ & 0,642 & 0,626 & 0,64 & 0,636 & & & 0,95 \\
\hline \multirow{2}{*}{ DB } & $\begin{array}{c}\mathrm{c}_{\mathrm{a}} \\
{[\mathrm{kN} / \mathrm{mm}]}\end{array}$ & 0,654 & 0,641 & 0,648 & 0,648 & \multirow[b]{2}{*}{0,95} & \multirow[b]{2}{*}{0,97} & \multirow[b]{2}{*}{0,97} \\
\hline & $\begin{array}{c}\mathrm{c}_{\mathrm{b}} \\
{[\mathrm{kN} / \mathrm{mm}]}\end{array}$ & 0,622 & 0,626 & 0,634 & 0,627 & & & \\
\hline \multirow{2}{*}{$\begin{array}{c}\text { Wartość } \\
\text { śred- } \\
\text { nia/Average } \\
\text { value } \\
\end{array}$} & $\begin{array}{c}\mathrm{c}_{\mathrm{a}} \\
{[\mathrm{kN} / \mathrm{mm}]}\end{array}$ & 0,662 & 0,663 & 0,661 & 0,662 & \multirow[b]{2}{*}{0,95} & \multirow[b]{2}{*}{0,95} & \multirow[b]{2}{*}{0,95} \\
\hline & $\begin{array}{c}\mathrm{c}_{\mathrm{b}} \\
{[\mathrm{kN} / \mathrm{mm}]}\end{array}$ & 0,629 & 0,631 & 0,633 & 0,631 & & & \\
\hline \multicolumn{2}{|c|}{$\begin{array}{l}\text { Wartość obliczeniowa/ Cal- } \\
\text { culated value }[\mathrm{kN} / \mathrm{mm}]\end{array}$} & 0,647 & 0,645 & 0,712 & & & & \\
\hline
\end{tabular}


tance trial is carried out) is:

for new springs $\mathrm{c}_{\mathrm{b}}=0,6099 \mathrm{~mm} / \mathrm{kN}$,

$>$ for lubricated springs $c_{b}=0,590 \div 0,616 \mathrm{~mm} / \mathrm{kN}$,

$>$ for non-lubricated and worn springs $c_{b}=0,5457 \div 0,5585 \mathrm{~mm} / \mathrm{kN}$.

The values, that were set by the SNCF, NS, and DB railway management boards in the new state, are shown in Table 5. The values of susceptibility, that were set for springs with the repaired leaves and in "non-lubricated" state, are shown in Table 6.
Podatność wyznaczona przy obciążeniu wzrastającym $\mathrm{c}_{\mathrm{b}}$ kształtuje się na poziomie 0,778 wartości średniej podatności w stanie nowym (różni się około 22,11\%). Przy obciążeniu wzrastającym też wykonywana jest próba odbiorcza tzn. $134 \mathrm{kN}$.

Należy jednak rozróżnić sens kryteriów odbiorczych.

$\mathrm{Na}$ rysunku 27R 070301-1-0, w normie PN-61/K88171 [8] oraz przepisach naprawczych OW-305 [9] sa przywołane dwie próby istotne $\mathrm{z}$ punktu widzenia funkcjonalności resoru tzn.:

\section{Zestawienie podatności resorów z piórami naprawianymi oraz w stanie „nie nasmarowanym” pomierzonych przez zarząd NS na stanowisku rolkowym. \\ List of susceptibility of springs with the repaired leaves and in the „non-lubricated" state measured by NS railway management boards on the roller stand.}

Tablica 6/ Table 6

\begin{tabular}{|c|c|c|c|c|c|}
\hline \multicolumn{6}{|c|}{$\begin{array}{l}\text { Badania resoru zamontowanego na stanowisku rolkowym } \\
\text { Tests of the spring mounted on the roller stand }\end{array}$} \\
\hline \multirow{2}{*}{$\begin{array}{l}\text { Oznaczenie resoru/ } \\
\text { Spring marking }\end{array}$} & \multirow{2}{*}{$\begin{array}{l}\begin{array}{l}\text { Obciążenie wzrasta- } \\
\text { jące/ Increasing load }\end{array} \\
\mathrm{c}_{\mathrm{b}}[\mathrm{mm} / \mathrm{kN}]\end{array}$} & \multirow{2}{*}{$\begin{array}{c}\text { Obciążenie } \\
\begin{array}{c}\text { Zmniejszające/ De- } \\
\text { creasing load }\end{array} \\
\mathbf{c}_{\mathrm{c}}[\mathrm{mm} / \mathrm{kN}]\end{array}$} & \multicolumn{2}{|c|}{$\begin{array}{l}\text { Wartość średnia/ } \\
\text { Average value }\end{array}$} & \multirow{2}{*}{$\begin{array}{c}\text { Tarcie wewnętrzne }{ }^{1)} \\
\text { Internal friction } \\
{[\mathbf{m m} / \mathbf{k N}]}\end{array}$} \\
\hline & & & $\begin{array}{c}\mathbf{c}_{\mathrm{a}} \\
{[\mathrm{mm} / \mathrm{kN}]}\end{array}$ & $\frac{c_{a}{ }^{2)}}{c_{a o b l}}$ & \\
\hline 1 & 0,51 & 0,68 & 0,59 & 0,91 & 0,159 \\
\hline 2 & 0,50 & 0,66 & 0,60 & 0,93 & 0,172 \\
\hline 3 & 0,50 & 0,66 & 0,58 & 0,89 & 0,158 \\
\hline $\begin{array}{l}\text { Wartość średnia/ } \\
\text { Average value }\end{array}$ & 0,50 & 0,67 & 0,59 & 0,91 & 0,163 \\
\hline
\end{tabular}

1) 1 wartości zostały ustalone wg obciążeń ustalonych w karcie UIC 821[5] tzn. $F_{1}=20 \mathrm{kN}$ oraz $\mathrm{F}_{2}=90 \mathrm{kN} /$ values were set according to the loads specified in UIC 821[5]i.e.. $\mathrm{F}_{1}=20 \mathrm{kN}$ and $\mathrm{F}_{2}=90 \mathrm{kN}$

${ }^{2)}$ przy obliczeniu wskaźnika przyjęto obliczeniową wartość podatności wynoszącą $0,642 \mathrm{~mm} / \mathrm{kN}$ /at calculation of the index

it was taken a calculated value of susceptibility of $0,642 \mathrm{~mm} / \mathrm{kN}$

From the presented results it appears that the average value of the susceptibility, which is determined at the measuring stand for the springs with the repaired leaves and "non-lubricated" springs, differs from the average value in the new state by $9,65 \% \div 6,54 \%$.

The susceptibility determined at the increasing load $\mathrm{c}_{\mathrm{b}}$ is at level of 0,778 of the mean value of susceptibility in the new state of (differs by about 22,11\%). At the increasing load the acceptance test is also carried out i.e. $134 \mathrm{kN}$.

However, it must be differentiated the meaning of the acceptance criteria.

In drawing 27R 070301-1-0, in PN-61/K-88171 [8] and OW-305 repair regulations [9] two tests significant for the functionality of the spring are referred to i.e.:

$>$ susceptibility test $0,64 \pm 8 \%$,

$>$ deflection test under test load $134 \mathrm{kN}$, at which deflection should be $87,3 \pm 8 \%$.

The susceptibility of the spring (or its stiffness as an opposite) guarantees:

$>$ the height of the buffers in the empty state and in the loaded state within the limits stipulated by the regulations,

$>$ free space to guarantee the dynamic displacements,
$>$ próba podatności $0,64 \pm 8 \%$,

> próba ugięcia pod obciążeniem próbnym 134 $\mathrm{kN}$, przy którym ugięcie powinno wynosić $87,3 \pm 8 \%$.

Podatność resoru (lub jego sztywność jako odwrotność) gwarantuje:

$>$ wysokość zderzaków w stanie próżnym oraz $\mathrm{w}$ stanie ładownym $\mathrm{w}$ granicach zastrzeżonych przepisami,

$>$ wolną przestrzeń dla zagwarantowania dynamicznych przemieszczeń,

$>$ ograniczenie maksymalnego ugięcia, tak aby uniknąć przeciążenia resoru,

$>$ bezpieczną jazdę wagonu po torach wykazujących maksymalną, dopuszczalną wartość wichrowatości własnej,

> zagwarantowanie utrzymania zarysu skrajni kinematycznej wg karty UIC 505-1 [2].

Wielkość tarcia wewnętrznego pomiędzy piórami resoru wynikająca $\mathrm{z}$ różnicy podatności $\mathrm{c}_{\mathrm{b}}$ i $\mathrm{c}_{\mathrm{c}}$ wynika z następujących czynników:

$>$ stanu powierzchni poszczególnych piór (chropowatość powierzchni),

$>$ obecności smaru pomiędzy piórami,

$>$ obecności zanieczyszczeń i korozji pomiędzy piórami. 
$>$ limiting the maximum deflection to avoid the overload of spring,

$>$ safe ride of wagon on tracks with maximum permissible value of own twist,

$>$ guarantee the maintenance of the kinematic clearance gauge outline according to UIC 505$1[2]$.

The size of internal friction between the spring leaves resulting from the difference of susceptibility $c_{b}$ and $c_{c}$ results from the following factors:

$>$ surface condition of individual leaves (surface roughness),

$>$ presence of grease between leaves,

$>$ presence of pollution and corrosion between the leaves.

Distribution of friction forces in the spring depends on the number of leaves.

In order to determine the meaning of carrying out the second tests, it is necessary to establish how the size of load of $134 \mathrm{kN}$ was determined. Force of $134 \mathrm{kN}$ as an acceptance criterion for this type of springs is also reported in ORE/ERRI B12 Rp.25 [7]. In the standard drawing ORE/ERRI 2 Fwg 711.0.02.021.001 a bit higher value of $137 \mathrm{kN}$ is given, at which the nominal deflection at three tested springs is $81 \mathrm{~mm}, 79 \mathrm{~mm}$ and $82 \mathrm{~mm}$ respectively [3].

If it taken the gross weight of the wagon in the loaded state on bogies 1 XTa being $80000 \mathrm{~kg}$, the weight of the wheelset with axle-boxes is $1243 \mathrm{~kg}$ (weight of wheelset $1101 \mathrm{~kg}$ according to drawing 3XT0901-1-0 and two sets of axle- boxes with bearings with $71 \mathrm{~kg}$ according to drawing X0923-1-0), the spring weight of $116 \mathrm{~kg}$, then the weight per spring is:

$$
\mathrm{kg}
$$$$
\mathrm{m}_{\mathrm{GROSS}}=0,125 \cdot(80 \quad 000-4 \cdot 1101-8 \cdot 71-8 \cdot 116)=9262,5
$$

This force determined as $90 \mathrm{kN}$ is the force determined for defining the susceptibility according to UIC 821 [5] which corresponds to the force of $90,865 \mathrm{kN}$ and results from the weight of the wagon loaded up to the load limit, which corresponds to the axleload of $20 \mathrm{t}$. Therefore it is possible to determine that the force that was set as the acceptance one results from a maximum dynamic surplus of $k=\frac{134}{90}=1,488 \approx 1,5 \quad$ (that is about $50 \%$ ).

If the gross weight of the empty wagon on the bogies "1XTa" is assumed as $20000 \mathrm{~kg}$ and the remaining mass parameters as for the dependence (42), then the mass per one spring is:

$$
\mathrm{m}_{\text {EMPTY }}=0,125 \cdot(20000-4 \cdot 1101-8 \cdot 71-8 \cdot 116)=1762,5 \mathrm{~kg}
$$

which corresponds to $17,290 \mathrm{kN}$.

Mass of $20000 \mathrm{~kg}$ is accepted as a so-called. ,equivalent mass", which serves to accept the bogie in an empty state.
Rozdział sił tarcia w resorze zależy od ilości piór. Aby można było określić sens przeprowadzenia drugiej próby należy ustalić $\mathrm{w}$ jaki sposób ustalono wielkość obciążenia $134 \mathrm{kN}$. Siła $134 \mathrm{kN}$ jako kryterium odbiorcze dla tego typu resorów jest podana na również w raporcie ORE/ERRI B12 Rp.25 [7]. Na rysunku standardowym ORE/ERRI 2 Fwg 711.0.02.021.001 podano nieco większą wartość 137 $\mathrm{kN}$, przy której nominalne ugięcie wynosi przy trzech przebadanych resorach odpowiednio $81 \mathrm{~mm}, 79 \mathrm{~mm}$ oraz $82 \mathrm{~mm}$ [3].

Jeśli przyjać masę brutto wagonu w stanie ładownym na wózkach 1XTa wynoszącą $80000 \mathrm{~kg}$, masę omaźnicowanego zestawu kołowego $1243 \mathrm{~kg}$ (masa zestawu $1101 \mathrm{~kg}$ wg rys. 3XT0901-1-0 oraz dwa komplety maźnic z łożyskami po $71 \mathrm{~kg}$ wg rys. X0923-1-0), masę resoru $116 \mathrm{~kg}$ wówczas masa przypadająca na jeden resor wynosi:

$\mathrm{m}_{\text {BRUTTO }}=0,125 \cdot(80000-4 \cdot 1101-8 \cdot 71-8 \cdot 116)=9262,5 \mathrm{~kg}$

Siła ta ustalona jako $90 \mathrm{kN}$ jest siłą wyznaczoną do określenia podatności wg karty UIC 821 [5] co odpowiada sile $90,865 \mathrm{kN}$ i wynika $\mathrm{z}$ masy wagonu załadowanego aż do granicy ładowności, co odpowiada naciskowi zestawu kołowego na tor wynoszącemu 20 t.

Można więc ustalić, że siła która została ustalona jako odbiorcza wynika z maksymalnej nadwyżki dynamicznej wynoszącej $k=\frac{134}{90}=1,488 \approx 1,5 \quad$ (czyli około $50 \%$ ).

Jeśli przyjąć masę brutto wagonu w stanie próżnym na wózkach „1XTa” wynosząca $20000 \mathrm{~kg}$ o pozostałe parametry masowe jak dla zależności (42) wówczas masa przypadająca na jeden resor wynosi:

$$
\mathrm{m}_{\mathrm{PRÓŻNY}}=0,125 \cdot(20 \quad 000-4 \cdot 1101-8 \cdot 71-8 \cdot 116)=1762,5
$$

co odpowiada sile $17,290 \mathrm{kN}$.

Masa $20000 \mathrm{~kg}$ jest przyjęta jako tzw. „masa ekwiwalentna", która służy do odbioru wózka w stanie próżnym.

Można, więc postawić tezę, że siły $90 \mathrm{kN}$ (stan ładowny wagonu odpowiadający naciskowi zestawu kołowego na tor 20t) oraz $20 \mathrm{kN}$ (w przybliżeniu stan próżny zostały uznane w karcie UIC 821[5] jako siły odbiorcze przy wyznaczaniu podatności resoru, jeśli nie podano innych wartości na rysunku (na rysunku konstrukcyjnym 27R070301-1-0, jak również w przepisach naprawczych takich wartości nie podano).

Metodyka wyznaczania podatności $\mathrm{c}_{\mathrm{a}}$ podana $\mathrm{w}$ karcie UIC 821 [5] polega w takim przypadku na jej wyznaczeniu w oparciu o następujący wzór:

$$
c_{a}=\frac{\left(H_{1 C}+H_{1 D}\right)-\left(H_{2 C}+H_{2 D}\right)}{2 \cdot\left(F_{2}-F_{1}\right)}
$$


Therefore it can be put forward the thesis that the forces of $90 \mathrm{kN}$ (load state of the wagon corresponding to the axleload of 20t) and $20 \mathrm{kN}$ (approximately the empty state ) were accepted in UIC $821[5]$ as the acceptance forces for determining the spring susceptibility if other values were not specified in the drawing (in constructional drawing 27R070301$1-0$, as well as such values were not given in the repair regulations).

The methodology for determining the susceptibility $c_{a}$ given in UIC 821 [5] in that case consists in its determining based on the following formula:

$$
c_{a}=\frac{\left(H_{1 C}+H_{1 D}\right)-\left(H_{2 C}+H_{2 D}\right)}{2 \cdot\left(F_{2}-F_{1}\right)}
$$

From the formula (44) the algorithm of activities results that must be carried out to determine the susceptibility:

$>$ spring load $\mathrm{F}_{1}$ and height record $\mathrm{H}_{1 \mathrm{c}}$,

$>$ load increasing from $\mathrm{F}_{1}$ to $\mathrm{F}_{2}$ and height record $\mathrm{H}_{2 \mathrm{c}}$,

$>$ load increasing from $F_{2}$ to $F_{m}$,

$>$ decreasing load from $\mathrm{F}_{\mathrm{m}}$ to $\mathrm{F}_{2}$ and height record $\mathrm{H}_{2 \mathrm{~d}}$,

$>$ decreasing load from $F_{2}$ to $F_{1}$ and height record $\mathrm{H}_{1 \mathrm{~d}}$,

$>$ spring unloading.

The value of internal friction is calculated from the dependence:

$$
T=\frac{H_{2 c}-H_{2 d}}{H_{2 c}+H_{2 d}} .
$$

All measuring quantities are shown in Fig. 2

Therefore, it can be concluded that the deflection test under the load of $134 \mathrm{kN}$ with a tolerance of $87,3 \pm 8 \%$ in any case does not determine the susceptibility $c_{a}$ in the way in accordance with the regulations. Tolerance of height under load of $\pm 8 \%$ can show about the susceptibility value $c_{b}$ (that is on the loading down curve) which also changes during operation. In case of riding on the twisted tracks, the wheelset is relieved, but on the curve with susceptibility $\mathrm{c}_{\mathrm{z}}$ showing the higher susceptibility (low stiffness), from where it can be further concluded that with all kind of kinematic constraints (and this nature has riding on the twisted tracks) the small changes of the vertical forces on the wheels (wheels are relieved) correspond to the large deformations. Confirmation for the different values of susceptibility in the new state is the drawing of the spring ORE/ERRI 2Fwg 825.02.021.01, where the following values of susceptibility and their mutual relations are given:

$\mathrm{c}_{\mathrm{a}}=0,662 \mathrm{~mm} / \mathrm{kN}, \mathrm{c}_{\mathrm{b}}=0,631 \mathrm{~mm} / \mathrm{kN}, \mathrm{c}_{\mathrm{z}}=0,718 \mathrm{~mm} / \mathrm{kN}$

$$
\text { , } \frac{c_{b}}{c_{a}}=0,954, \frac{c_{z}}{c_{a}}=1,085 \text {. }
$$

In order to prove that the force of $134 \mathrm{kN}$ is the maximum force corresponding to the dynamic surplus, the
Z wzoru (44) wynika algorytm czynności, które należy wykonać a celu ustalanie podatności:

$>$ obciążenie resoru $\mathrm{F}_{1} \mathrm{i}$ rejestracja wysokości $\mathrm{H}_{1 \mathrm{c}}$,

$>$ obciążenie wzrastające od $\mathrm{F}_{1}$ do $\mathrm{F}_{2}$ i rejestrację wysokości $\mathrm{H}_{2 \mathrm{c}}$,

$>$ obciążenie wzrastające od $\mathrm{F}_{2}$ do $\mathrm{F}_{\mathrm{m}}$,

$>$ obciążenie malejące od $\mathrm{F}_{\mathrm{m}}$ do $\mathrm{F}_{2} \mathrm{i}$ rejestracja wysokości $\mathrm{H}_{2 \mathrm{~d}}$,

$>$ obciążenie malejące od $\mathrm{F}_{2}$ do $\mathrm{F}_{1}$ i rejestracja wysokości $\mathrm{H}_{1 \mathrm{~d}}$,

$>$ odciążenie resoru.

Wartość tarcia wewnętrznego oblicza się z zależności:

$$
T=\frac{H_{2 c}-H_{2 d}}{H_{2 c}+H_{2 d}} .
$$

Wszystkie wielkości pomiarowe przedstawiono na rys. 2



Rys.2. Wyznaczanie wielkości pomiarowych w celu ustalenia podatności resoru wg karty UIC 821 [5]

Fig.2. Determination of measuring values to determine the spring susceptibility according to UIC 821 [5]

Można więc wnioskować, że próba ugięcia pod obciążeniem $134 \mathrm{kN} \mathrm{z}$ tolerancją wysokości 87,3 $\pm 8 \%$ w żadnym wypadku nie ustala podatności $\mathrm{c}_{\mathrm{a}} \mathrm{W}$ sposób zgodny z przepisami. Tolerowanie wysokości pod obciążeniem $\pm 8 \%$ może świadczyć o wartości podatności $c_{b}$ (czyli na krzywej dociążającej), która także zmienia się $w$ trakcie eksploatacji. W przypadku jazdy przez tory wichrowate następuje odciążenie zestawu kołowego, ale już na krzywej o podatności $\mathrm{c}_{\mathrm{z}}$ wykazującej większą podatność (małą sztywność), skąd można wyciagnąć dalej wniosek, że przy wszelkiego rodzaju wymuszeniach kinematycznych (a taki charakter ma przejazd przez tory wichrowate) dużym odkształceniom odpowiadają małe zmiany sił pionowych na kołach (odciążenia kół). Potwierdzeniem na różne wartości podatności w stanie nowym jest rysunek resoru ORE/ERRI 2Fwg 825.02.021.01, gdzie są podane następujące wartości podatności i ich wzajemne relacje: 
spring deflection arrow can be calculated from the empty state corresponding to the equivalent mass of $20000 \mathrm{~kg}$ (then there is a force of $17,290 \mathrm{kN}$ per spring) according to dependence:

(46)

$$
f_{O D B}=c_{a} \cdot\left(F_{D Y N}-F_{P R}\right)
$$

After inserting the numerical data i.e.: $\mathrm{c}_{\mathrm{a}}=0,642$ $\mathrm{mm} / \mathrm{kN}, F_{D Y N}=134 \mathrm{kN}$ oraz $F_{P R}=17,290 \mathrm{kN}$ it is obtained:

$$
f_{O D B}=0,642 \cdot(134-17,290)=74,92 \mathrm{~mm}
$$

This value corresponds to the distance between the spring hoop and the bumper welded to the top solebar flange $74_{-6}^{+2} \mathbf{m m}$. This distance is listed in drawing 1XTa 0701-1 (bogie's configuration).

In drawing 1XTa 0701-2 (bogie's configuration) and in drawing 1XTa070800-11-00 ( configuration of spring suspension) the distance between bumper and the spring hoop was increased to $80^{+6} \mathrm{~mm}$. Therefore, assuming the force in empty state of 17,986 $\mathrm{kN}$ and the new distance to the bumper, the value of force acting on the spring is given:

$$
F_{D Y N}=F_{P R}+\frac{1}{c_{a}} \cdot f_{O D B}
$$

Inserting the numerical data into dependence (48) i.e. $\mathrm{F}_{\mathrm{PR}}=17,290 \mathrm{kN}, \mathrm{c}_{\mathrm{a}}=0,642 \mathrm{~mm} / \mathrm{kN}$ and $\mathrm{f}_{\mathrm{ODB}}=80 \mathrm{~mm}$ it is obtained:

$$
F_{D Y N}=17,290+\frac{1}{0,642} \cdot 80=141,9 k N \approx 142 k N
$$

This corresponds to the increased maximum dynamic surplus that must be taken into account in the construction of the bogie and amounting

$$
k=\frac{141,9}{90}=1,576 \approx 1,6
$$

\section{CONCLUSIONS}

According to the presented analyses, the characteristics of the spring changes during operation. This has a significant impact on the process of safe riding in twisted-track conditions, which will be shown in next publications on this topic. A very important process is the process of qualifying the spring during repairs, i.e. checking the full characteristic of the spring, thus determining the hysteresis loop. This loop has the decisive character in the process of qualifying the usefulness of the spring for further operation. Testing the deflection of spring under the test load is not a reliable test and it may only be considered as an information or supplementary test. This topic will be continued in the next publications. $\mathrm{c}_{\mathrm{a}}=0,662 \mathrm{~mm} / \mathrm{kN}, \mathrm{c}_{\mathrm{b}}=0,631 \mathrm{~mm} / \mathrm{kN}, \mathrm{c}_{\mathrm{z}}=0,718 \mathrm{~mm} / \mathrm{kN}$

$$
, \frac{c_{b}}{c_{a}}=0,954, \frac{c_{z}}{c_{a}}=1,085 .
$$

W celu udowodnienia, że siła $134 \mathrm{kN}$ jest maksymalną siłą odpowiadającą nadwyżce dynamicznej można przeprowadzić obliczenie strzałki ugięcia resoru od stanu próżnego odpowiadającego masie ekwiwalentnej $20000 \mathrm{~kg}$ (wtedy na resor przypada siła $17,290 \mathrm{kN}$ ) wg zależności:

$$
f_{O D B}=c_{a} \cdot\left(F_{D Y N}-F_{P R}\right)
$$

Po wstawieniu danych liczbowych tzn.: $\mathrm{c}_{\mathrm{a}}=0,642$ $\mathrm{mm} / \mathrm{kN}, \mathrm{F}_{\mathrm{DYN}}=134 \mathrm{kN}$ oraz $\mathrm{F}_{\mathrm{PR}}=17,290 \mathrm{kN}$ otrzymuje się:

$$
f_{O D B}=0,642 \cdot(134-17,290)=74,92 \mathrm{~mm}
$$

Wartość ta odpowiada odległości pomiędzy opaską resorową i odbijakiem przyspawanym do górnego pasa ostojnicy $74_{-6}^{+2} \mathbf{m m}$. Odległość ta jest wymieniona na rys.1XTa 0701-1 (zestawienie wózka). Na rysunku 1XTa 0701-2 (zestawienie wózka) oraz na rysunku 1XTa070800-11-00 ( zestawienie podwieszenia resoru) odległość pomiędzy odbijakiem oraz opaską resorową zwiększono do $\mathbf{8 0}^{+6} \mathrm{~mm}$. W związku z tym przyjmując siłę przypadającą w stanie próżnym 17,986 kN oraz nową odległość do odbijaka otrzymuje się wartość siły działającej na resor wynoszącą:

$$
F_{D Y N}=F_{P R}+\frac{1}{c_{a}} \cdot f_{O D B}
$$

Podstawiając wartości liczbowe do zależności (48) tzn. $F_{P R}=17,290 \mathrm{kN}, c_{\mathrm{a}}=0,642 \mathrm{~mm} / \mathrm{kN}$ oraz $\mathrm{f}_{\mathrm{ODB}}=80$ mm otrzymuje się:

$$
F_{D Y N}=17,290+\frac{1}{0,642} \cdot 80=141,9 k N \approx 142 k N
$$

Odpowiada to zwiększonej maksymalnej nadwyżce dynamicznej, którą trzeba uwzględnić w konstrukcji wózka i wynoszącej $k=\frac{141,9}{90}=1,576 \approx 1,6$.

\section{WNIOSKI}

Jak wynika z przedstawionych analiz, charakterystyka resoru zmienia się $\mathrm{w}$ trakcie eksploatacji. Ma to istotny wpływ na proces bezpiecznej jazdy w warunkach jazdy przez tory wichrowate, co zostanie wykazane w następnych publikacjach na ten temat. Bardzo ważnym procesem jest proces kwalifikacji resoru podczas napraw, czyli sprawdzenie pełnej charakterystyki resoru, określając tym samym pętlę histerezy. Pętla ta ma charakter rozstrzygający w procesie kwalifikacji użyteczności resoru do dalszej eksploatacji. Badanie ugięcia resoru pod obciążeniem próbnym, nie jest badaniem miarodajnym, a może być jedynie traktowane jako badanie informacyjne lub uzupełniajace. Tematyka ta będzie kontynuowana w następnych publikacjach. 
[1] Sobaś M: Zawieszenia i układy biegowe pojazdów szynowych. Wydawnictwo IPS Tabor. 2014.

[2] Karta UIC 505-1: Pojazdy kolejowe. Skrajnie pojazdów. 9-te wydanie z listopada 2003.

[3] Karta UIC 517: Wagony towarowe. Części zawieszenia resorowego. Normalizacja. 6-te wydanie z 1.01.1979, nowy naktad z 1.01.1989 z 10-ta zmiana z 1.07.1997

[4] Karta UIC 820: Warunki techniczne dla dostawy stali sprężynowej płaskiej dla resorów piórowych i sprężyn stożkowych. 6-te wydanie z grudnia 2003.

[5] Karta UIC 821: Warunki techniczne dostawy resorów piórowych dla pojazdów. 6-te wydanie z listopada 2003.

[6] Raport ORE/ERRI B12/Rp14/D: Vereinheitlichung der Güterwagen. Standard-Drehge-stell. Bericht 14. Listopad 1967.

[7] Raport ORE/ERRI B12.Bericht Nr. 25: Spezifische Federung der Trapezfedern. Utrecht. Wrzesień 1986 (2Ausgabe).

[8] PN-61/K-88181: Tabor kolejowy. Wagony towarowe. Resory piórowe.

[9] WT-2 cz.4a-4c, OW305 : Warunki techniczne kwalifikacji do naprawy, naprawy i odbioru po naprawie sprężyn nośnych wagonów towarowych. 